九州大学学術情報リポジトリ

Kyushu University Institutional Repository

Techno-Economic Comparative Analysis between Grid-Connected and Stand-Alone Integrated Energy Systems for an Educational Institute

Siva Subrahmanyam Mendu

Department of Mechanical Engineering, MVGR College of Engineering (A)

Appikonda, Padmaja

Department of Electrical and Electronics Engineering, JNTUK-UCEV

Anil Kumar Emadabathuni

Department of Mechanical Engineering, Indian Institute of Technology Tirupati

https://doi.org/10.5109/4068616

出版情報：Evergreen. 7 (3)，pp.382-395，2020-09. 九州大学グリーンテクノロジー研究教育センター バージョン：

権利関係 : 


\title{
Techno-Economic Comparative Analysis between Grid- Connected and Stand-Alone Integrated Energy Systems for an Educational Institute
}

\author{
Siva Subrahmanyam Mendu ${ }^{1, *}$, Padmaja Appikonda ${ }^{2}$, Anil Kumar Emadabathuni ${ }^{3}$, \\ Naresh Koritala ${ }^{2}$ \\ ${ }^{1}$ Department of Mechanical Engineering, MVGR College of Engineering (A), Vizianagaram, India \\ ${ }^{2}$ Department of Electrical and Electronics Engineering, JNTUK-UCEV, Vizianagaram, India \\ ${ }^{3}$ Department of Mechanical Engineering, Indian Institute of Technology Tirupati, Tirupati, India \\ *Author to whom correspondence should be addressed: \\ E-mail:m.sivasubrahmanyam@gmail.com
}

(Received March 31, 2020; Revised August 2, 2020; accepted August 24, 2020).

\begin{abstract}
Promoting green energy initiatives are vital in educational institutes to encounter the energy demand and providing a sustainable life. In the most part, solar and wind energy options are chosen as renewable energy projects to meet part of electricity demand. However, because of the intermittent nature of these sources, alternative technologies should be chosen to provide effective and sustainable solutions. Various energy resources need to be combined in order to provide effective and efficient power generation. The present paper therefore focuses on the feasibility study of integrated energy systems for the energy supply of the educational institution. The work examines the techno-economic performance of various grid-connected and stand-alone integrated energy systems for an educational institute for making a decision before implementing green energy technologies. First, the energy demand is estimated for the entire campus. Further, the potential of renewable energy resources is assessed using NASA and NREL. A detailed survey was carried out to select the components required to model the various integrated energy systems. The modelling, optimization and economic study are performed using HOMER Pro software. A comparative economic analysis is made among considered integrated systems using Net Present Cost (NPC), COE and pay-back period. The study divulges that the grid-connected hybrid system is the optimal one for meeting the power demand of the institute in a reliable manner.
\end{abstract}

Keywords: Integrated energy system; Solar/ Wind energy; Diesel generators, HOMER Pro.

\section{Introduction}

Educational institutions are in great need to maintain or upgrade their prevailing infrastructure to suit the growing economy and demand for education. This swift in infrastructural expansion will lead to more power demand by these institutions. Most of the current infrastructural needs of institutions are exclusively dependent on conventional energy. Currently, maximum of the electricity is produced from burning fossil fuel resources like coal, oil and gas. The usage of these resources causes pollution and climate changes. It is very important to minimize the pollution and climate changes by using renewable energy resources as an alternative to fossil fuels resources. However, the country's economy depends on fossil fuels. As the energy demand is ever increasing, the only effective elucidation is to utilize the available and feasible renewable energy sources effectively. Further, the renewable energy based technologies should be adopted in all sectors before the exhaust of fossil fuel resources ${ }^{1)}$. The renewable energy is obtained from sun, wind, bio mass, water etc. moreover renewable energy sources are pollution free, eco-friendly and accessible at free of cost.

Solar and wind resources are considered as intermittent energy sources because they are seasonal specific. For these two types of renewable energy, wind energy is the more effected source if compared to the solar energy due to its inconsistency. Similarly, the stand-alone systems containing these two unpredictable energy sources will produce varied output energy and thus cannot guarantee the continuity of power for meeting the necessary load requirement. To overcome the above mentioned problems, integrated energy systems are developed ${ }^{2}$. The addition of different energy resources makes the system to produce continuous output energy without any fluctuations. In general hybrid energy systems contain 
diesel generators, loads, renewable energy resources, energy storage, power converters, etc. ${ }^{3)}$.

The hybrid systems can be categorized as stand-alone and grid-connected. The former systems are normally used in isolated places where the extension of grid network is not feasible and locations where grid failures occurs frequently ${ }^{4}$. On-grid hybrid systems are directly connected to the local utility grid. On-grid hybrid systems allow us to meet our load demand by integrating the renewable energy sources and grid. In these systems, the excess power is generally sold to the grid and shortage of energy is met by purchasing from the grid ${ }^{5)}$.

Few studies carried out on techno-economic performance assessment of On-grid and Off-grid hybrid energy systems are discussed here. Muselli et al.6) analysed the PV-Diesel generator based hybrid system and shown that the system has greater reliability in generating electrical energy. Bagen and Billinton ${ }^{7)}$ study reveal that the operating cost can be minimized by implementing solar-wind-diesel generator hybrid system. Givler and Lilienthal ${ }^{8)}$ showed that the PV/diesel system suits economically better than solar based systems. Rehman et al. ${ }^{9)}$ analysed the feasibility study of WindPV-Diesel hybrid energy system for a village and identified that the hybrid power systems exhibit higher reliability and lower cost of generation than the energy system based on single source of energy. Sen and Bhattacharyya $^{10)}$ designed stand-alone integrated energy system for a rural village and identified that the considered configuration is more cost-effective choice than conventional grid extension. Chade et al. ${ }^{11)}$ conducted hybrid energy system analysis for Grimsey Island and showed that a wind-hydrogen hybrid system is economically optimal. Amutha et al. ${ }^{12)}$ analyzed different combinations of hybrid energy systems for electrifying a village and observed that PV-Wind-Diesel generatorBattery integrated configuration is best choice among all other hybrid system combinations. Baghdadi et al. ${ }^{13)}$ compares the performance of diesel generator systems with the hybrid PV-Diesel-Wind-Battery system for electrifying remote regions and observed that $69 \%$ of conventional fuels can be saved if hybrid PV- DieselWind-Battery system is implemented. Though the above works mainly focused on economics of hybrid systems in small villages and islands, very few works are also devoted to economic analysis of hybrid energy systems for buildings. Singh and Baredar ${ }^{14)}$ performed technoeconomic assessment of a solar PV, fuel cell, and biomass gassifier hybrid energy system for energy centre MANIT Bhopal and observed that this system will generate an excess electricity of $36 \mathrm{kWh} /$ year with zero unmet electric load. Tomar and Tiwari ${ }^{15)}$ performed techno-economic evaluation of grid connected PV systems for households and observed that this system economically beneficial to household customers. Usman et al. ${ }^{16)}$ designed three hybrid system configurations for electrifying Faculty of Engineering and Technology department, Jamia Millia Islamia, and observed that PVGrid hybrid system is more cost-effective with lowest cost of energy of Rs 8.84/kWh. Kumar and Bhimasingu et al. ${ }^{17)}$ designed a PV-wind-diesel generator-battery-grid connected hybrid energy system for a building in a technical university and observed that the designed system is more economical and environment friendly, which leads to $6.18 \%$ of annual cost savings.

Most of the above studies indicate that little research is being done on the assessment of the techno-economic efficiency of hybrid energy systems in technical institutions. Furthermore, these studies are limited to a small building in a specific area. However, as per the author's knowledge, no work has been done on feasibility study of hybrid energy systems for the entire campus of the institute. In addition, meeting energy demand in an efficient and cost-saving manner depends on a variety of factors, such as location, availability of resources, load and government subsidies, technological and economic aspects of the various components of the energy system. Considering the above facts, the present work is focused on design and optimal sizing of integrated energy system for meeting the energy requirement in the entire campus of the institute considering the academic and residential areas of the institute in northern coastal district of Andhra Pradesh in India. Four different hybrid energy systems are designed and carried out simulations to meet the energy demand of the campus and comparative study is made to provide an economic feasible solution.

\section{Energy assessment at location}

The JNTUK-University college of Engineering Vizianagaram (UCEV) is located in the rural village of Dwarapudi in the Vizianagaram district of Andhra pradesh in India. The campus is having a primary load requirement of $1814 \mathrm{kWh} /$ day with a peak value of $214.99 \mathrm{~kW}$ and a deferrable load of $85.50 \mathrm{kWh} /$ day with a peak value of $28.50 \mathrm{~kW}$. The primary load demands are the electrical load demands that the hybrid system can serve at a specific time whereas deferrable load demands are the electrical load demands that can be met any time with a specific time intervals. Water pumping is considered as a deferrable load. The primary load summary of the campus is shown in Fig. 1. It is perceived that the maximum energy requirement is in March and April between $6.00 \mathrm{pm}$ to $11.00 \mathrm{pm}$. This is due to the fact that during these hours in summer all the lightening loads, electrical fans and air conditioners in residential area of the campus consumes majority of electrical energy. The deferrable load profile of the campus is shown in Fig. 2. The deferrable load of the campus is seen to be less in the month of May. This is due to the fact that during this month, summer holidays are given to students, so that the operating motor load on hostel blocks is almost negligible. 


\subsection{Solar energy data}

The JNTUK-UCEV campus located at latitude of $18^{\circ}$ $9.1^{\circ}$ North and $82^{\circ} 22.5^{\circ}$ East. The annual average solar radiation at the specified location is taken from National Aeronautics and Space Administration (NASA) resource website $^{18)}$. The yearly average solar energy available at the location is $4.82 \mathrm{kWh} / \mathrm{m}^{2} /$ day. The monthly average of clearness index and solar radiation is shown in Fig. 3.

\subsection{Wind energy data}

The annual average wind speed at the campus location is $4.64 \mathrm{~m} / \mathrm{s}$ and the altitude of campus location is $129 \mathrm{~m}$


Fig. 1: Primary load profile of the campus.

Hour above from sea level ${ }^{19)}$. The diurnal pattern strength is 0.25 and the auto correlation factor is $0.85^{20}$. The monthly average wind

speed over a year is shown in Fig. 4. From solar and wind data, it is seen that the solar energy available is less in July and August months whereas, the wind speed is high in these two months. So high wind speed in July and August months compensates the less solar radiation effect and makes total renewable resources to be available throughout the year.
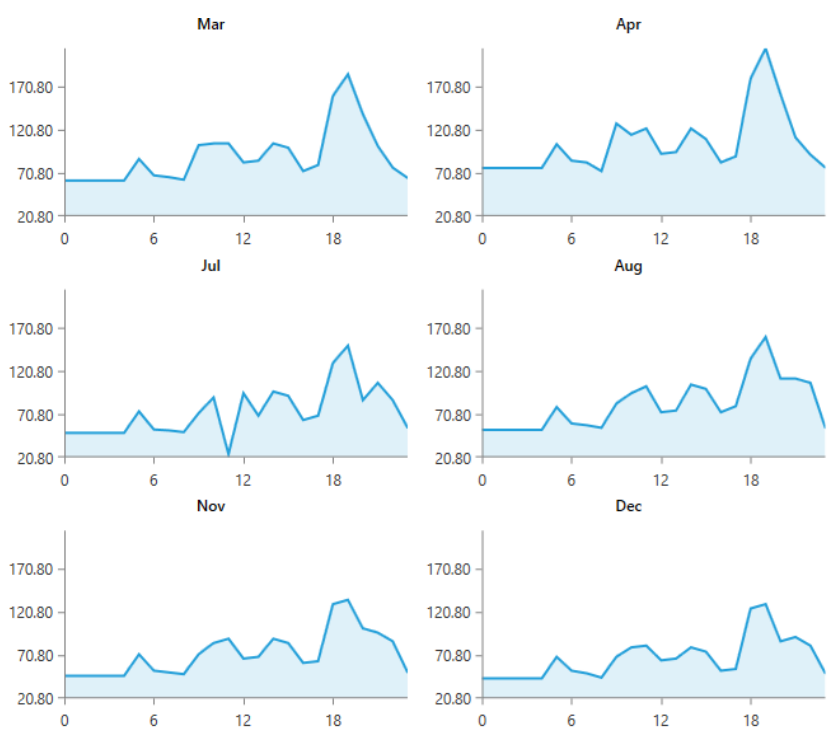

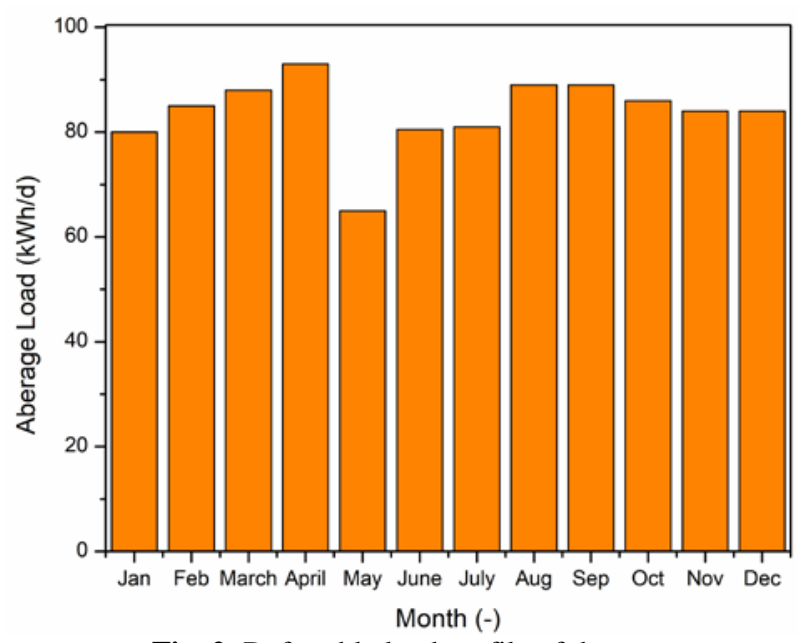

Fig. 2: Deferrable load profile of the campus.

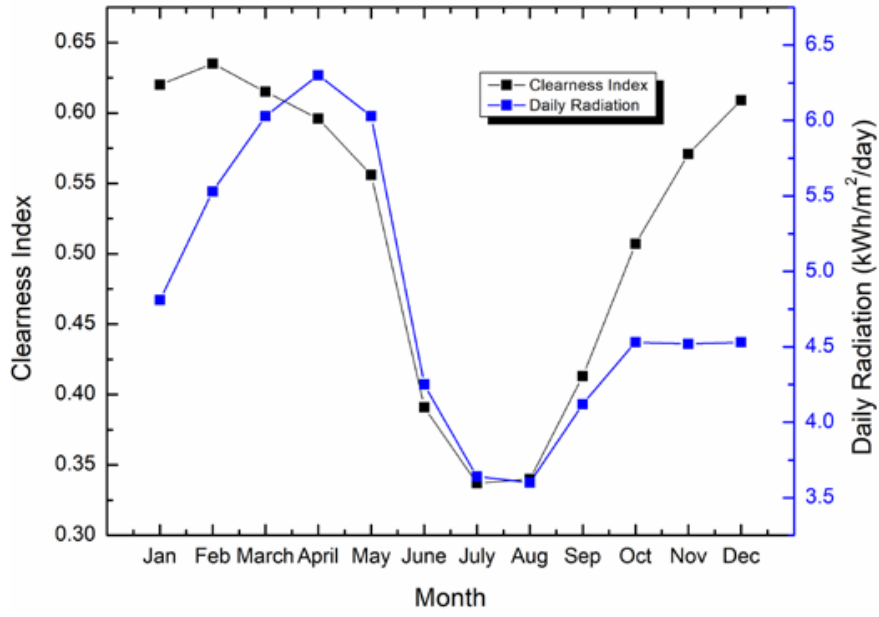

Fig. 3: Solar energy data at the campus location. 


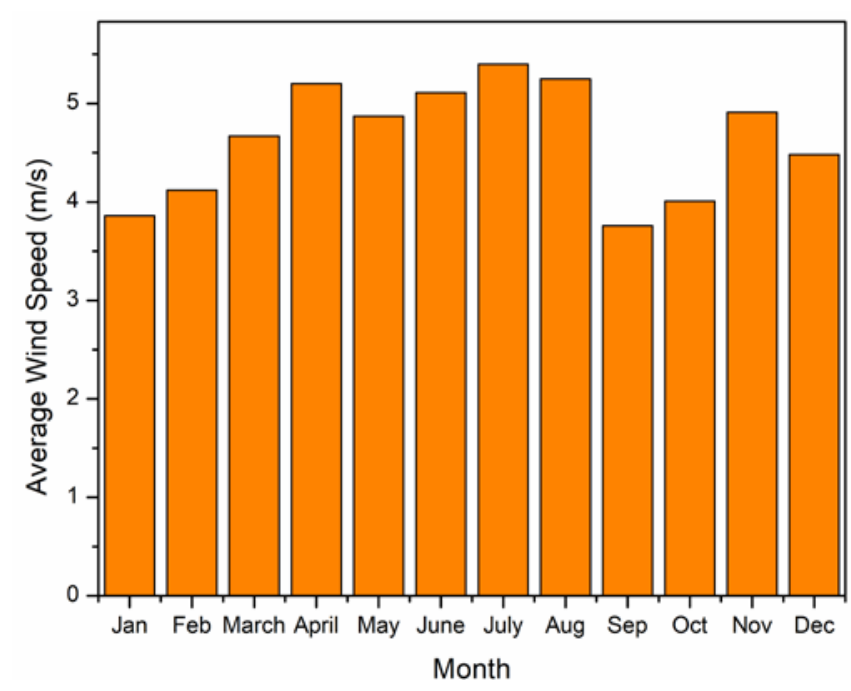

Fig. 4: Wind energy data at the campus location

\section{Methodology}

The present section confers the methodology and design aspects of different integrated systems for supplying the optimal power generation to the considered educational institute. For this study, the HOMER software is used to model various interconnected energy systems complemented by the HOMER pre-evaluation and post-analysis. The detailed methodology followed in the present work is shown in Fig.5.

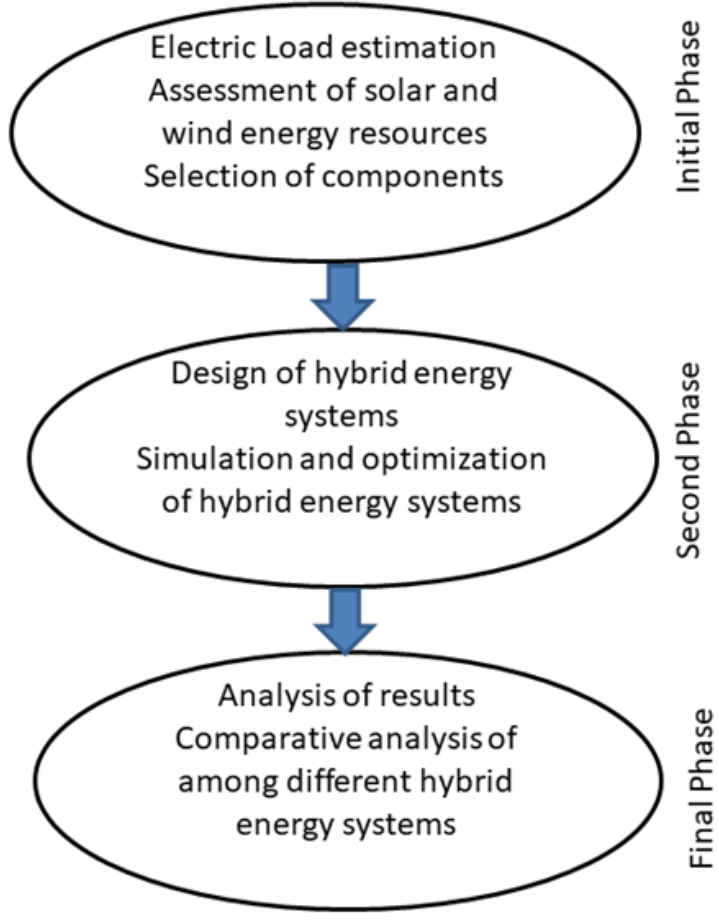

Fig.5. Methodology adopted in the present work
The work has been conducted in three stages. In the initial phase of the study, a comprehensive electrical load assessment was carried out separately for the academic and residential parts of the institute. The full load profile of the institute as a whole was evaluated with the aid of load data collected from the institute's academic and residential campuses. Then, the availability of solar and wind energy resources at the location is measured using data from the National Aeronautics and Space Administration (NASA) information website. In addition, a detailed survey was conducted on the selection of each part of the hybrid energy system on the basis of technical and economic requirements. During the second phase of research, four different hybrid energy systems were designed to take into account load data, resources and different components using HOMER pro software. Moreover, simulations and optimization of the different hybrid energy systems are carried out. In the final step of the study, a thorough analysis of the optimal hybrid energy systems was carried out and a comparative analysis was carried out between the various hybrid energy systems to make a decision on the optimal hybrid energy system to satisfy the energy needs of the educational institution.

\subsection{Economic and technical specifications}

The economic and technical specifications of different components that are used in modelling of hybrid energy systems are discussed in forthcoming sub sections.

\subsubsection{Solar PV system}

SunPower E20-327(SPR-PV) model solar panels are considered for the study. The capital and replacement cost of $1 \mathrm{~kW}$ solar panel are chosen as $\$ 615$ and $\$ 584$ separately. The life span of solar panel is 25 years. Derating factor of PV panel is taken as $88 \%$ and the 
ground reflectance is considered as $20 \%{ }^{22)}$. The performance of the PV array shall be calculated as ${ }^{14)}$

$$
P_{\text {out }}=P_{\mathrm{NPV}}\left(G / G_{\text {ref }}\right)\left[1+K_{\mathrm{T}}\left(T_{\mathrm{C}}-T_{\text {ref }}\right)\right]
$$

\subsubsection{Wind turbine}

A Whisper 200 series (Wh200) model wind turbine is considered in this work. The capital, replacement, operation and maintenance (O\&M) cost per $\mathrm{kW}$ are chosen as \$1000, \$923 and \$9.23 individually. The life period is 20 years and a hub height of $12.5 \mathrm{~m}^{23)}$. The Whisper wind turbine gives DC power output. The wind speed at the hub height can be calculated using logarithmic law as

$U_{\text {hub }}=U_{\text {anem }} \frac{\ln \left(Z_{\text {hub }} / Z_{\text {o }}\right)}{\ln \left(Z_{\text {anem }} / Z_{\text {o }}\right)}$

The wind speed at the hub height can be calculated using power law as

$$
U_{\text {hub }}=U_{\text {anem }}\left(\frac{Z_{\text {hub }}}{Z_{\text {anem }}}\right)^{\alpha}
$$

In order to conform to the actual conditions, the power value expected by the power curve is multiplied by the air density ratio, according to the equation.

$$
P_{\mathrm{wTG}}=\left(\frac{\rho}{\rho_{0}}\right) P_{\mathrm{wTG}, \mathrm{STP}}
$$

\subsubsection{Converter}

A Solax X3-hybrid 10 model converter is chosen for study. The per $\mathrm{kW}$ capital, replacement and O\&M cost of converter are chosen as \$277, \$261 and \$9.23 separately. The life of converter is 15 years with an efficiency of $97 \%{ }^{9)}$.

\subsubsection{Batteries}

The batteries considered for this study are Exide 6LMS model. It is a 12 volts battery with a nominal capacity of $100 \mathrm{Ah}$ and life time of 10 years and round trip efficiency of $80 \%{ }^{24)}$. The capital, replacement and O\&M cost of battery are considered as \$161.5, \$131 and \$4.6 respectively. The storage capacity $\left(C_{\mathrm{Wh}}\right)$ is calculated by the equation ${ }^{14)}$

$$
C_{\text {wh }}=\left(\mathrm{E}_{\mathrm{L}} \times \mathrm{AD}\right) \eta_{\text {inv }} \eta_{\mathrm{b}} \mathrm{DOD}
$$

\subsubsection{Diesel generators}

There are total five generators already installed in JNTUK-UCEV campus. They are Kirloskar generator(G1)-100 kW, Ashokleyland generator (G2)-50 kW, Kirloskar generator (G3)-50 kW, Kirloskar generator (G4)-50 kW, Kirloskar generator (G5)-50 kW. The initial capital cost of all generators is taken as zero as these were already part of the institute. The replacement and O\&M cost of generator G1 are chosen as $\$ 8461$ and $\$ 3.8$. For generator G2 the replacement and O\&M cost are $\$ 6153$ and \$1.92. The replacement and O\&M costs of generators G3, G4 and G5 are considered as \$6923 and $\$ 1.92$. The cost of diesel per litre is taken as $\$ 1$. The output power equation of generator is given by equation $^{17)}$

$F=F_{0} Y_{\text {gen }}+F_{1} P_{\text {gen }}$

\subsubsection{System economics and constraints}

The life of the complete system is considered as 25 years. The expected Inflation rate is $2 \%$. The Nominal discount of $6 \%{ }^{25)}$ is considered. The maximum annual capacity shortage is taken as $0 \%$ and the simulation time step is taken as $60 \mathrm{~min}^{26)}$.

\subsubsection{Grid input}

The cost of electricity purchased by JNTUK-UCEV campus from APEPDCL is $\$ 0.145 / \mathrm{kWh}$. The excess electricity generated by the Grid connected hybrid systems could be selling back to the grid with a feed in tariff of $\$ 0.08 / \mathrm{kWh}$.

\subsection{Modelling of different hybrid energy systems}

In the present section, four different hybrid systems are modelled by considering technical and economic specifications of different components which are discussed in the last section. Two grid-connected and two stand-alone hybrid energy systems are modelled with the help of Hybrid Optimized Model for Electric Renewables (HOMER Pro) software ${ }^{21)}$ in the present study. They are

$\begin{array}{ll}\text { Case } & \text { PV-Wind- Diesel generator hybrid system. } \\ \text { 1: } & \\ \text { Case } & \text { PV-Diesel generator hybrid system. } \\ \text { 2: } & \\ \text { Case } & \text { PV-Wind-Diesel generator-Grid connected } \\ \text { 3: } & \text { hybrid system. } \\ \text { Case } & \text { PV-Diesel generator-Grid connected hybrid } \\ \text { 4: } & \text { system. }\end{array}$ energy system is discussed in forthcoming sub sections.

\subsubsection{Case1}

In this hybrid model, all five diesel generators in the campus are considered along with PV arrays, wind turbines and batteries. Fig. 6 depicts the hybrid model of the Case1. Solar and wind are considered as primary sources for generation of electrical energy. The PV arrays are mostly operates during day time and the wind turbines operate throughout the day. Whenever, the electric energy Requirement is not produced by the primary energy sources, the generators operate and fulfil the demand. The battery is used to store electrical energy when the supply exceeds the demand. Further, the converter is added in the design to convert DC power to AC. 


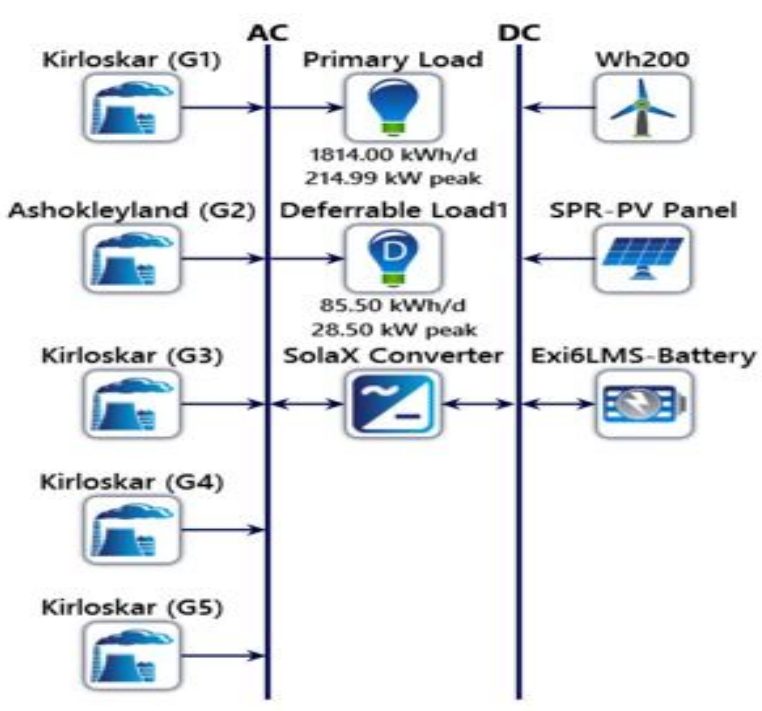

Fig. 6: PV-Wind-Diesel generators hybrid energy system.

\subsubsection{Case 2}

The model presented in this section is similar to the earlier model except the omission of wind turbine. The HOMER simulation model is shown in Fig. 7. All the five generators connected in this hybrid system are acts as secondary sources of electrical energy.

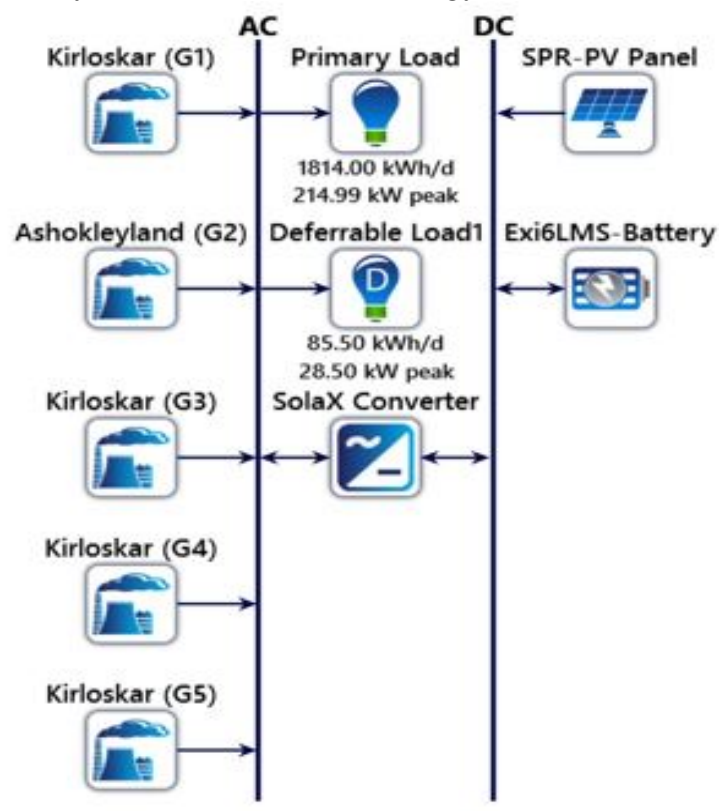

Fig. 7: PV-Diesel generators hybrid energy system.

\subsubsection{Case 3}

The first two cases are focused on design of standalone integrated systems. In the present case, the hybrid system is connected local grid as shown in Fig.8. The primary renewable energy resources such as Solar and wind are taken. The storage battery is not included in the present model as the hybrid system is coupled to the grid. The additional energy generated than demand is sold to the grid and energy could be purchased when the demand exceeds the generated power.



Fig.8: PV-Wind-Diesel generators- Grid connected hybrid energy system.

\subsubsection{Case 4}

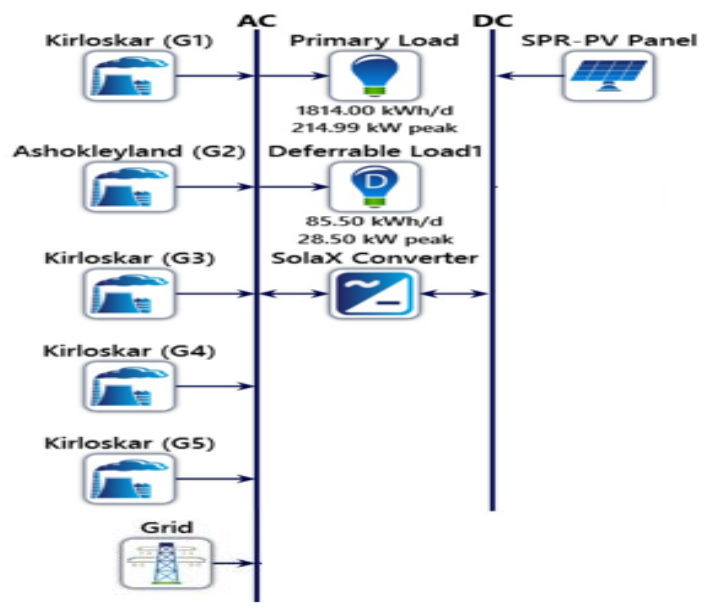

Fig. 9: PV-Diesel generators- Grid connected hybrid energy system.

In Case 4, the solar energy is only considered as primary energy resource. The HOMER simulation model of case 4 is depicted in Fig. 9. In both of these grid connected hybrid system models the diesel generators and utility grid are acts as secondary sources of electrical energy.

\subsection{Economic Modelling of hybrid energy systems}

Economics plays a significant role in both the simulation and optimization phase of HOMER. In the simulation phase, the device works to minimize overall net present costs. In the optimization process, the device configuration looks for the lowest overall net present expense. 
The total net present cost is the life-cycle cost of the hybrid energy system. The system with the lowest net present cost is thus the best hybrid energy configuration. The following equation is used to measure the salvage value of each item at the end of the project life. ${ }^{14)}$

$$
S=C_{\text {rep }} \frac{R_{r e m}}{R_{\text {comp }}}
$$

For each component, the capital, replacement, O\&M and fuel costs shall be combined with the salvage value and any other expense to calculate the annualized cost of the component. The following equation is used to calculate the total net present cost ${ }^{14)}$.

$$
N P C=\frac{C_{a n n, t o t}}{C R F\left(i, R_{\text {proj }}\right)}
$$

$\mathrm{CRF}$ is the capital recovery factor given by the equation ${ }^{21)}$.

$$
C R F(i, N)=\frac{i(1+i)^{N}}{(1+i)^{N}-1}
$$

The following equation is used to calculate the levelized cost of energy ${ }^{14)}$

$$
C O E=\frac{C_{a n n, t o t}}{E_{\text {prim }}+E_{d e f}+E_{\text {grid,sales }}}
$$

\section{Results \& Discussion}

Simulations are carried out for all the cases of integrated energy systems using HOMER pro. The optimal solution for the economic power generation for each case is identified based on net present cost. The Net Present Cost (NPC) is used to provide the Rank to various possible configurations of the system. The optimal solution will be decided based on the lowest NPC value. The optimization results and economic features of all four models are discussed in forthcoming sub sections.

\subsection{Case1}

The optimization results of Case1are shown in Table 1. The first row of Table 1 represents the first rank and it is considered as the optimal system design that meets the electrical energy requirement of the campus. NPC and Cost of Electricity (COE) of the optimal hybrid configuration are $\$ 1752942$ and $\$ 0.161$ respectively. Table 1 shows the optimal arrangement for Case1. It comprises a $500 \mathrm{~kW}$ PV panel, five $1 \mathrm{~kW}$ wind turbines, 100 kW Kirloskar generator (G1), 50 kW Ashokleyland generator (G2), 50 kW Kirloskar generator (G3), 50 kW Kirloskar generator (G4), $50 \mathrm{~kW}$ Kirloskar generator (G5), 1200 Exide batteries and $250 \mathrm{~kW}$ converter.

Table 1. Optimization results of PV-Wind-Diesel

\begin{tabular}{|c|c|c|c|c|c|c|c|c|c|c|c|}
\hline $\begin{array}{c}\text { SVR-PV } \\
(\mathrm{kW})\end{array}$ & Wh20 & $\begin{array}{c}\mathrm{G} 1 \\
(\mathrm{~kW})\end{array}$ & $\begin{array}{c}\mathrm{G} 2 \\
(\mathrm{~kW})\end{array}$ & $\begin{array}{c}\mathrm{G} 3 \\
(\mathrm{~kW})\end{array}$ & $\begin{array}{c}\mathrm{G} 4 \\
(\mathrm{~kW})\end{array}$ & $\begin{array}{c}(\mathrm{G} 5) \\
(\mathrm{kW})\end{array}$ & Exi6LMS & $\begin{array}{c}\text { Solax Con } \\
(\mathrm{kW})\end{array}$ & $\begin{array}{c}\text { Disp } \\
\text { COE } \\
(\$)\end{array}$ & $\begin{array}{c}\text { NPC } \\
(\$)\end{array}$ \\
\hline 500 & 5 & 100 & 500 & 50 & 50 & 50 & 1200 & 250 & LF & 0.161 & $1.75 \mathrm{M}$ \\
\hline 500 & 5 & 100 & 500 & - & - & - & 1200 & 250 & LF & 0.161 & $1.76 \mathrm{M}$ \\
\hline 500 & 5 & 100 & 500 & 50 & 50 & - & 1200 & 250 & LF & 0.161 & $1.76 \mathrm{M}$ \\
\hline 500 & 5 & 100 & 500 & 50 & - & 50 & 1200 & 250 & LF & 0.161 & $1.76 \mathrm{M}$ \\
\hline 500 & 5 & 100 & 500 & - & 50 & 50 & 1200 & 250 & LF & 0.161 & $1.76 \mathrm{M}$ \\
\hline
\end{tabular}

Table 2. Annual electricity production of optimal hybrid energy system components

\begin{tabular}{|c|c|c|}
\hline Production & $\mathbf{k W h} / \mathbf{y r}$ & $\mathbf{\%}$ \\
\hline SPR-PV Panel & 727153 & 82.9 \\
\hline Kirloskar (G1) & 88412 & 10.1 \\
\hline Ashokleyland (G2) & 48490 & 5.53 \\
\hline Kirloskar (G3) & 852 & 0.0972 \\
\hline Kirloskar (G4) & 30 & 0.00342 \\
\hline Kirloskar (G5) & 0 & 0 \\
\hline Wh200 & 12068 & 1.38 \\
\hline Total & 877005 & 100 \\
\hline
\end{tabular}

The amount of annual electrical energy generated by each component of optimal hybrid configuration is presented in Table 2. It indicates that the total yearly electricity produced to satisfy the required load is 877005 $\mathrm{kWh} /$ year. It is perceived that the $82.9 \%$ of electricity demand is met by PV panels, $1.38 \%$ electric load demand is met by Wind turbines,
$10.1 \%$ of load demand is met by Kirloskar generator (G1), 5.53\% electricity is supplied from Ashokleyland generator (G2) and $0.0972 \%, 0.00342 \%$ of load demand is met by Kirloskar generator (G3) and Kirloskar generator (G4). HOMER considers all generators in the best optimal system configuration to take their salvage values in to account. The monthly average electrical energy produced by each component of optimal hybrid energy system configuration is shown in Fig. 10.

The costs of different components of the Case 1 during the life period of the complete system are shown in Table 3. 
It is observed that the contribution of total cost of Batteries, PV panels and Kirloskar generator (G1) is maximum in NPC of the system. Further, the total cost of G1 (27.11\% of the total system cost) is more as compared to the solar PV panels despite the lower share of its generating power than Solar PV.

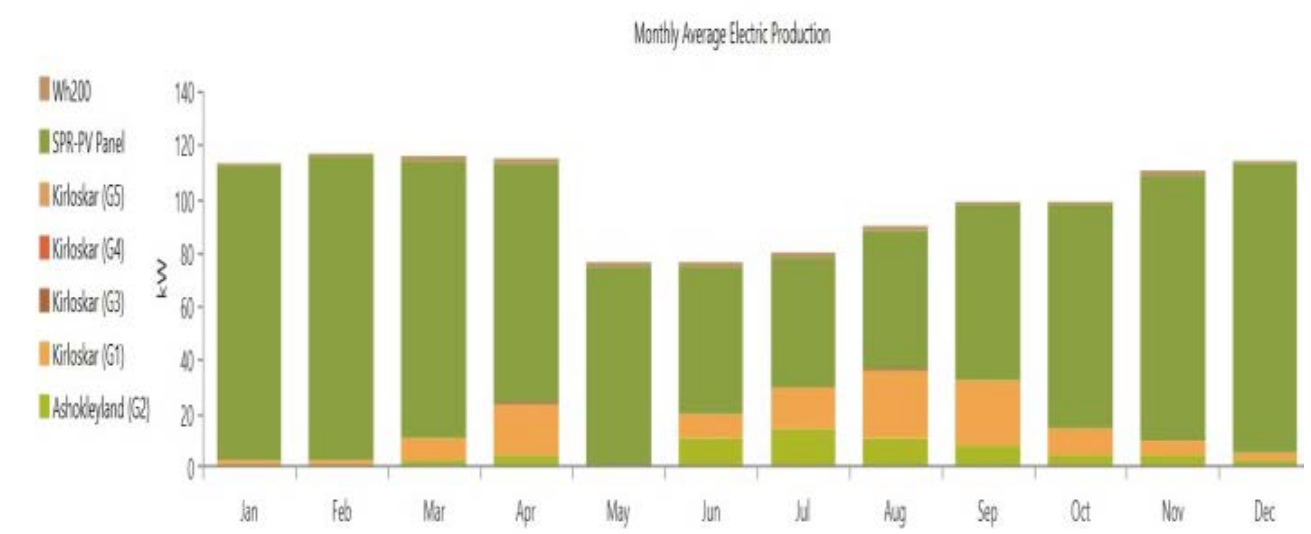

Fig. 10: Monthly average electrical energy generated by individual components of Case1.

Table 3: Cost summary of optimal hybrid energy system components

\begin{tabular}{|c|c|c|c|c|c|c|}
\hline Name & $\begin{array}{c}\text { Capital } \\
\mathbf{( \$ )}\end{array}$ & $\begin{array}{c}\text { O\&M } \\
\mathbf{( \$ )}\end{array}$ & $\begin{array}{c}\text { Replacement } \\
\mathbf{( \$ )}\end{array}$ & $\begin{array}{c}\text { Salvage } \\
\mathbf{( \$ )}\end{array}$ & $\begin{array}{c}\text { Fuel } \\
\mathbf{( \$ )}\end{array}$ & $\begin{array}{c}\text { Total } \\
\mathbf{( \$ )}\end{array}$ \\
\hline Ashokleyland (G2) & 0.00 & 37413 & 2421 & -2280 & 203297 & 240850 \\
\hline Exi 6LMS Battery & 193800 & 86953 & 179838 & -30046 & 0.00 & 430545 \\
\hline Kirloskar (G1) & 0.00 & 79074 & 3532 & -2908 & 395647 & 475345 \\
\hline Kirloskar (G2) & 0.00 & 1391 & 0.00 & -2545 & 5116 & 3963 \\
\hline Kirloskar (G3) & 0.00 & 60.49 & 0.00 & -2642 & 189.97 & 2392 \\
\hline Kirloskar (G4) & 0.00 & 0.00 & 0.00 & $-2,580$ & 0.00 & 2,580 \\
\hline Other & 13846 & 145395 & 0.00 & 0.00 & 0.00 & 159241 \\
\hline SolaX X3-hybrid10 & 69250 & 36349 & 36643 & -8314 & 0.00 & 133928 \\
\hline SPR-PV Panel & 307500 & 0.00 & 0.00 & 0.00 & 0.00 & 307500 \\
\hline Wh200 & 5000 & 726.97 & 2,138 & -1323 & 0.00 & 6542 \\
\hline System & 589396 & 387362 & 224572 & -52638 & 604250 & 1752942 \\
\hline
\end{tabular}

Table 4. Optimization results of PV-Diesel generators hybrid energy system

\begin{tabular}{|c|c|c|c|c|c|c|c|c|c|c|}
\hline $\begin{array}{c}\text { SVR-PV } \\
(\mathrm{kW})\end{array}$ & $\begin{array}{c}\mathrm{G} 1 \\
(\mathrm{~kW})\end{array}$ & $\begin{array}{c}\mathrm{G} 2 \\
(\mathrm{~kW})\end{array}$ & $\begin{array}{c}\mathrm{G} 3 \\
(\mathrm{~kW})\end{array}$ & $\begin{array}{c}\mathrm{G} 4 \\
(\mathrm{~kW})\end{array}$ & $\begin{array}{c}(\mathrm{G} 5) \\
(\mathrm{kW})\end{array}$ & Exi6LMS & $\begin{array}{c}\text { Solax Con } \\
(\mathrm{kW})\end{array}$ & $\begin{array}{c}\text { Disp } \\
\text { COE } \\
(\$)\end{array}$ & $\begin{array}{c}\text { NPC } \\
(\$)\end{array}$ \\
\hline 510 & 100 & 50 & 50 & 50 & 50 & 1200 & 250 & LF & 0.162 & $1.77 \mathrm{M}$ \\
\hline 510 & 100 & 50 & 50 & 50 & 50 & 1300 & 250 & LF & 0.162 & $1.77 \mathrm{M}$ \\
\hline 510 & 100 & 50 & - & - & - & 1200 & 250 & LF & 0.162 & $1.77 \mathrm{M}$ \\
\hline 510 & 100 & 50 & 50 & 50 & - & 1200 & 250 & LF & 0.162 & $1.77 \mathrm{M}$ \\
\hline 510 & 100 & 50 & 50 & - & 50 & 1200 & 250 & LF & 0.162 & $1.77 \mathrm{M}$ \\
\hline
\end{tabular}

\subsection{Case 2}

The optimization results of Case 2 considered for overall area are shown in Table 4.The NPC and COE of the optimal hybrid configuration are $\$ 1765177$ and $\$ 0.162$ respectively. From Table 4, the optimal hybrid system configuration is selected. It consists of a $510 \mathrm{~kW}$ PV panel, $100 \mathrm{~kW}$ Kirloskar generator (G1), $50 \mathrm{~kW}$ Ashokleyland generator (G2), 50 kW Kirloskar generator (G3), 50 kW Kirloskar generator (G4), 50 kW Kirloskar generator (G5), 1200 Exide batteries and a $250 \mathrm{~kW}$ converter. The amount of annual electric power produced by individual power developing devices of optimal configuration is noted in Table 5. It is seen that the total annual electricity generated to satisfy the energy requirement is 882408 $\mathrm{kWh} /$ year. Approximately, 84.1\% of electricity demand is met by PV panels, $10.3 \%$ of load demand is met by Kirloskar generator (G1), 5.55\% electricity is generated from Ashokleyland generator (G2) and 0.0964\%, 
$0.00340 \%$ of total generated is produced by Kirloskar generator (G3) and Kirloskar generator (G4).

Table 5: Annual electricity production of optimal hybrid energy system components

\begin{tabular}{|c|c|c|}
\hline Production & $\mathbf{k W h} / \mathbf{y r}$ & $\mathbf{\%}$ \\
\hline SPR-PV panel & 741696 & 84.1 \\
\hline Kirloskar (G1) & 90862 & 10.3 \\
\hline Ashokleyland (G2) & 48970 & 5.55 \\
\hline Kirloskar (G3) & 851 & 0.0964 \\
\hline Kirloskar (G4) & 30 & 0.00340 \\
\hline Kirloskar (G5) & 0 & 0 \\
\hline Total & 882408 & 100 \\
\hline
\end{tabular}

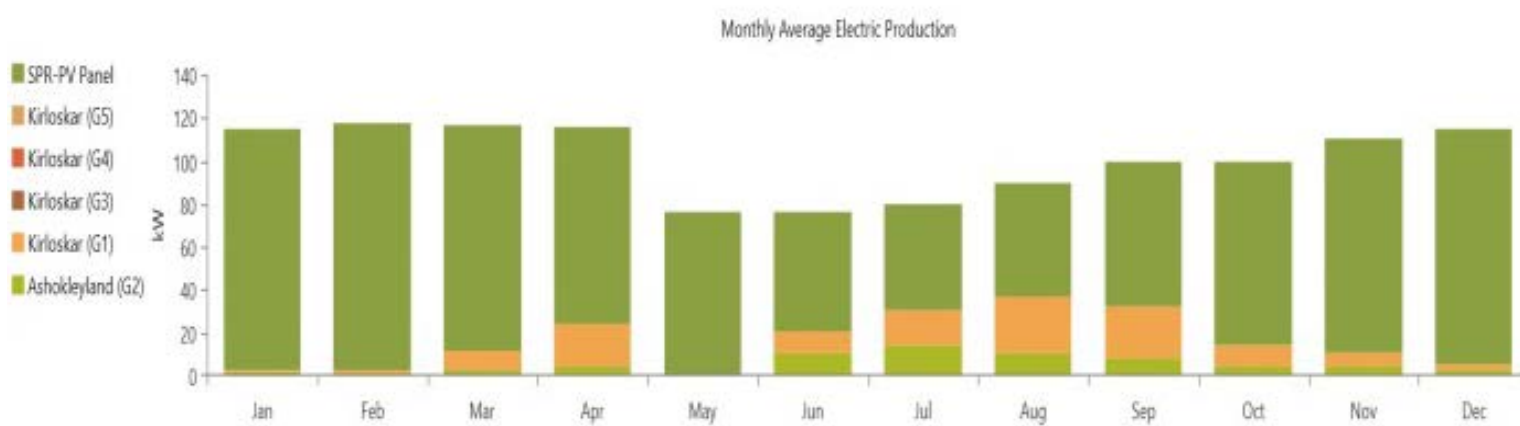

Fig. 11: Monthly average electricity production of optimal hybrid energy system components.

Table 6: Cost summary of optimal integrated energy system components

\begin{tabular}{|c|c|c|c|c|c|c|}
\hline Name & $\begin{array}{c}\text { Capital } \\
\mathbf{( \$ )}\end{array}$ & $\begin{array}{c}\mathbf{O \& M} \\
\mathbf{( \$ )}\end{array}$ & $\begin{array}{c}\text { Replacement } \\
\mathbf{( \$ )}\end{array}$ & $\begin{array}{c}\text { Salvage } \\
\mathbf{( \$ )}\end{array}$ & $\begin{array}{c}\text { Fuel } \\
\mathbf{( \$ )}\end{array}$ & $\begin{array}{c}\text { Total } \\
\mathbf{( \$ )}\end{array}$ \\
\hline Ashokleyland (G2) & 0.00 & 37292 & 2413 & -2287 & 204605 & 242023 \\
\hline Exi 6LMS Battery & 193800 & 86953 & 179838 & -30046 & 0.00 & 430545 \\
\hline Kirloskar (G1) & 0.00 & 80271 & 3578 & -2854 & 405871 & 486866 \\
\hline Kirloskar (G3) & 0.00 & 1361 & 0.00 & -2547 & 5082 & 3896 \\
\hline Kirloskar (G4) & 0.00 & 60.49 & 0.00 & -2642 & 189.97 & -2392 \\
\hline Kirloskar (G5) & 0.00 & 0.00 & 0.00 & -2580 & 0.00 & -2580 \\
\hline Other & 13846 & 145395 & 0.00 & 0.00 & 0.00 & 159241 \\
\hline SolaX Converter & 69250 & 36349 & 36643 & -8314 & 0.00 & 133928 \\
\hline SPR-PV Panel & 313650 & 0.00 & 0.00 & 0.00 & 0.00 & 313650 \\
\hline System & 590546 & 387681 & 222473 & -51271 & 615749 & 1765177 \\
\hline
\end{tabular}

Table 7. Optimization results of PV-Wind-Diesel generators-Grid connected hybrid energy system

\begin{tabular}{|c|c|c|c|c|c|c|c|c|c|c|c|c|}
\hline $\begin{array}{c}\text { SVR-PV } \\
(\mathrm{kW})\end{array}$ & Wh200 & $\begin{array}{c}\mathrm{G} 1 \\
(\mathrm{~kW})\end{array}$ & $\begin{array}{c}\mathrm{G} 2 \\
(\mathrm{~kW})\end{array}$ & $\begin{array}{c}\mathrm{G} 3 \\
(\mathrm{~kW})\end{array}$ & $\begin{array}{c}\mathrm{G} 4 \\
(\mathrm{~kW})\end{array}$ & $\begin{array}{l}\text { (G5) } \\
(\mathrm{kW})\end{array}$ & Exi6LMS & $\begin{array}{l}\text { Grid } \\
(\mathrm{kW})\end{array}$ & $\begin{array}{c}\text { Solax Con } \\
(\mathrm{kW})\end{array}$ & Disp & $\begin{array}{c}\mathrm{COE} \\
(\$)\end{array}$ & $\begin{array}{c}\text { NPC } \\
(\$)\end{array}$ \\
\hline 500 & 5 & 100 & 50 & 50 & 50 & 50 & 300 & 215 & 250 & LF & 0.0638 & $1.06 \mathrm{M}$ \\
\hline 500 & 5 & 100 & 50 & 50 & 50 & 50 & 300 & 215 & 250 & LF & 0.0638 & $1.06 \mathrm{M}$ \\
\hline 500 & 5 & 100 & - & 50 & 50 & 50 & 300 & 215 & 250 & LF & 0.0639 & $1.06 \mathrm{M}$ \\
\hline 500 & 5 & 100 & - & 50 & 50 & 50 & 300 & 215 & 250 & LF & 0.0639 & $1.06 \mathrm{M}$ \\
\hline 500 & 5 & 100 & 50 & 50 & 50 & - & 300 & 215 & 250 & LF & 0.0640 & $1.06 \mathrm{M}$ \\
\hline
\end{tabular}

The monthly average electricity generated by the individual components of optimal hybrid energy system configuration is shown in Fig. 11. The costs of different components of the Case 2 during the life period of the complete system are shown in Table 6. It is perceived from the table that the total cost of each component follow the similar trend of Case1.However, the cost of the solar and G1 is increased minimally as compared to the Case 1. Further, the solar PV and G1 contribution in generating the power is marginally improved than the Case 1.

\subsection{Case 3}

The optimization results of Case 3 considered for overall area are revealed in Table 7. The NPC and cost of COE of the optimal hybrid system configuration are $\$ 1056667$ and $\$ 0.0638$ respectively. It is seen that the optimal configuration comprises a $500 \mathrm{~kW}$ PV panel, five 
$1 \mathrm{~kW}$ wind turbines, $100 \mathrm{~kW}$ Kirloskar generator (G1), $50 \mathrm{~kW}$ Ashokleyland generator (G2), $50 \mathrm{~kW}$ Kirloskar generator (G3), $50 \mathrm{~kW}$ Kirloskar generator (G4), $50 \mathrm{~kW}$ Kirloskar generator (G5) and a grid support of $215 \mathrm{~kW}$ (see in Table 7) The amount of annual electrical energy generated by individual components of optimal hybrid energy system configuration is shown in Table 8. It is seen that the share of solar PV in power generation is more (64.5\%). While, the grid share is $34.4 \%$. This shows that the nearly $64.5 \%$ energy is conserved as compared to the existing scenario of purchasing the entire power from the grid. The monthly average electrical energy generated by individual power devices of optimal configuration is shown in Fig. 12. The cost summary of various components of the optimal configuration during the life period is shown in Table 9. It is perceived from the table that the contribution of total cost of Grid and PV panels is maximum in NPC of the system. The amount of \$ 27669 spent to the local utility grid for purchasing electricity. The energy exchange between the hybrid energy system and the grid is presented in Table 10. It is observed that the annual net energy purchased is $30351 \mathrm{kWh}$.

Table 8. Annual electricity production of optimal hybrid energy system components

\begin{tabular}{|c|c|c|}
\hline Production & $\mathbf{k W h} / \mathbf{y r}$ & $\mathbf{\%}$ \\
& & \\
\hline SPR-PV Panel & 727153 & 64.5 \\
\hline Kirloskar (G1) & 0 & 0 \\
\hline Ashokleyland (G2) & 0 & 0 \\
\hline Kirloskar (G3) & 0 & 0 \\
\hline Kirloskar (G4) & 0 & 0 \\
\hline Kirloskar (G5) & 0 & 0 \\
\hline Wh200 & 12068 & 1.07 \\
\hline Grid purchases & 388328 & 34.4 \\
\hline Total & 1127549 & 100 \\
\hline
\end{tabular}

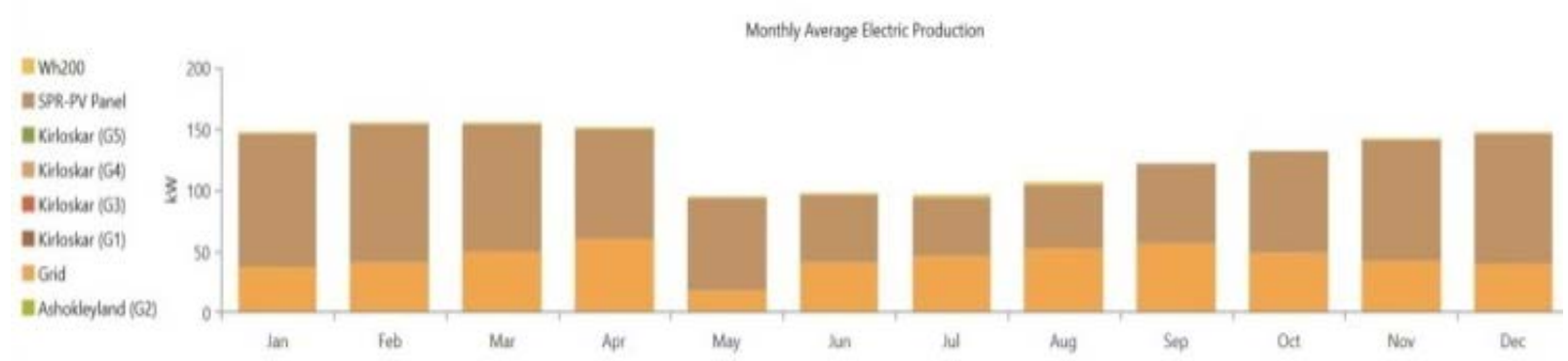

Fig. 12: Monthly average electrical energy generation of various components of optimal hybrid system.

Table 9. Cost summary of different components of optimal hybrid energy system

\begin{tabular}{|c|c|c|c|c|c|c|}
\hline Name & $\begin{array}{c}\text { Capital } \\
\mathbf{( \$ )}\end{array}$ & $\begin{array}{c}\text { O\&M } \\
\mathbf{( \$ )}\end{array}$ & $\begin{array}{c}\text { Replacement } \\
\mathbf{( \$ )}\end{array}$ & $\begin{array}{c}\text { Salvage } \\
\mathbf{( \$ )}\end{array}$ & $\begin{array}{c}\text { Fuel } \\
\mathbf{( \$ )}\end{array}$ & $\begin{array}{c}\text { Total } \\
\mathbf{( \$ )}\end{array}$ \\
\hline Ashokleyland (G2) & 0.00 & 0.00 & 0.00 & -2293 & 0.00 & -2293 \\
\hline Grid & 0.00 & 435859 & 0.00 & 0.00 & 0.00 & 435859 \\
\hline Kirloskar (G1) & 0.00 & 0.00 & 0.00 & -3153 & 0.00 & -3153 \\
\hline Kirloskar (G3) & 0.00 & 0.00 & 0.00 & -2580 & 0.00 & -2580 \\
\hline Kirloskar (G4) & 0.00 & 0.00 & 0.00 & -2580 & 0.00 & -2580 \\
\hline Kirloskar (G5) & 0.00 & 0.00 & 0.00 & -2580 & 0.00 & -2580 \\
\hline Other & 13846 & 145395 & 0.00 & 0.00 & 0.00 & 159241 \\
\hline SolaX X3-hybrid10 & 83100 & 43618 & 43972 & -9977 & 0.00 & 160713 \\
\hline SPR-PV Panel & 307500 & 0.00 & 0.00 & 0.00 & 0.00 & 307500 \\
\hline Wh200 & 5000 & 726.97 & 2138 & -1323 & 0.00 & 6542 \\
\hline System & 409446 & 625599 & 46110 & -24487 & 0.00 & 1056667 \\
\hline
\end{tabular}




\subsection{Case 4}

Table 10. Monthly Grid Energy Exchanges

\begin{tabular}{|c|c|c|c|c|c|}
\hline Month & $\begin{array}{c}\text { Energy } \\
\text { Purchased } \\
\mathbf{( k W h )}\end{array}$ & $\begin{array}{c}\text { Energy } \\
\text { Sold } \\
\mathbf{( k W h )}\end{array}$ & $\begin{array}{c}\text { Net } \\
\text { Energy } \\
\text { Purchased } \\
\mathbf{( k W h )}\end{array}$ & $\begin{array}{c}\text { Peak } \\
\text { Demand } \\
\mathbf{( k W )}\end{array}$ & $\begin{array}{c}\text { Energy } \\
\text { Charge } \\
\mathbf{( \$ )}\end{array}$ \\
\hline January & 27471 & 44773 & -17302 & 132 & 401.48 \\
\hline February & 27456 & 39471 & -12014 & 150 & 823.52 \\
\hline March & 37511 & 37759 & -247 & 185 & 2,418 \\
\hline April & 43644 & 27473 & 16171 & 215 & 4131 \\
\hline May & 13781 & 37805 & -24025 & 64.9 & -1026 \\
\hline June & 29497 & 15955 & 13542 & 157 & 3001 \\
\hline July & 34015 & 12837 & 21178 & 150 & 3905 \\
\hline August & 39348 & 13068 & 26280 & 160 & 4660 \\
\hline September & 40211 & 18991 & 21219 & 193 & 4311 \\
\hline October & 35981 & 30040 & 5941 & 155 & 2814 \\
\hline November & 30282 & 36157 & -5874 & 135 & 1498 \\
\hline December & 29129 & 43648 & -14519 & 130 & 731.89 \\
\hline Annual & 388328 & 357977 & 30351 & 215 & 27669 \\
\hline
\end{tabular}

Table 11. Optimization results of PV-Diesel generators-Grid-connected hybrid energy system

\begin{tabular}{|c|c|c|c|c|c|c|c|c|c|c|}
\hline $\begin{array}{c}\text { SVR-PV } \\
(\mathrm{kW})\end{array}$ & $\begin{array}{c}\mathrm{G} 1 \\
(\mathrm{~kW})\end{array}$ & $\begin{array}{c}\mathrm{G} 2 \\
(\mathrm{~kW})\end{array}$ & $\begin{array}{c}\mathrm{G} 3 \\
(\mathrm{~kW})\end{array}$ & $\begin{array}{c}\mathrm{G} 4 \\
(\mathrm{~kW})\end{array}$ & $\begin{array}{l}\text { (G5) } \\
(\mathrm{kW})\end{array}$ & $\begin{array}{l}\text { Grid } \\
(\mathrm{kW})\end{array}$ & $\begin{array}{c}\text { Solax Con } \\
(\mathrm{kW})\end{array}$ & Disp & $\begin{array}{c}\mathrm{COE} \\
(\$)\end{array}$ & $\begin{array}{c}\text { NPC } \\
(\$)\end{array}$ \\
\hline 500 & 100 & 50 & 50 & 50 & 50 & 215 & 300 & LF & 0.0648 & $1.07 \mathrm{M}$ \\
\hline 500 & 100 & 50 & 50 & 50 & 50 & 215 & 300 & LF & 0.0648 & $1.07 \mathrm{M}$ \\
\hline 500 & 100 & - & 50 & 50 & 50 & 215 & 300 & LF & 0.0659 & $1.07 \mathrm{M}$ \\
\hline 500 & 100 & - & 50 & 50 & 50 & 215 & 300 & LF & 0.0650 & $1.07 \mathrm{M}$ \\
\hline 500 & 100 & 50 & 50 & 50 & - & 215 & 300 & LF & 0.0650 & $1.07 \mathrm{M}$ \\
\hline
\end{tabular}

Table 12. Annual electricity production of optimal hybrid energy system components

\begin{tabular}{|c|c|c|}
\hline Production & $\mathbf{k W h} / \mathbf{y r}$ & $\mathbf{\%}$ \\
\hline Sunpower E20-327 & 727153 & 64.8 \\
\hline Kirloskar 125KVA & 0 & 0 \\
\hline Ashokleyland 63KVA & 0 & 0 \\
\hline Kirloskar 63KVA & 0 & 0 \\
\hline Kirloskar 63KVA(1) & 0 & 0 \\
\hline Kirloskar 63KVA(2) & 0 & 0 \\
\hline Grid purchases & 394868 & 35.2 \\
\hline Total & 1122021 & 100 \\
\hline
\end{tabular}

The optimization results of Case 4 are shown in Table 11. The NPC and COE of the optimal system configuration are $\$ 1069868$, and $\$ 0.0648$ respectively. From Table 11, it is seen that the optimal hybrid system configuration consists of a $500 \mathrm{~kW}$ PV panel, $100 \mathrm{~kW}$ Kirloskar generator (G1), 50 kW Ashokleyland generator (G2), 50 kW Kirloskar generator (G3), 50 kW Kirloskar generator (G4), $50 \mathrm{~kW}$ Kirloskar generator (G5), $300 \mathrm{~kW}$ converter and a Grid support of $215 \mathrm{~kW}$. The total annual electric power generated to meet the requirement is $1122021 \mathrm{kWh}$ (see in Table 12).
It is noted that $64.8 \%$ of the electrical energy is met from Solar PV and 35.2\% purchased from grid. The monthly average electrical energy generated by individual power devices of optimal configuration is shown in Fig.13. The various costs associated with hybrid system components during the project lifetime are shown in Table 13. It is seen from table that the contribution of total cost of grid and PV panels is maximum in NPC of the system.

Table 13. Cost summary of optimal hybrid energy system components

\begin{tabular}{|c|c|c|c|c|c|c|}
\hline Name & $\begin{array}{c}\text { Capital } \\
\mathbf{( \$ )}\end{array}$ & $\begin{array}{c}\mathbf{O \& M} \\
\mathbf{( \$ )}\end{array}$ & $\begin{array}{c}\text { Replacement } \\
\mathbf{( \$ )}\end{array}$ & $\begin{array}{c}\text { Salvage } \\
\mathbf{( \$ )}\end{array}$ & $\begin{array}{c}\text { Fuel } \\
\mathbf{( \$ )}\end{array}$ & $\begin{array}{c}\text { Total } \\
\mathbf{( \$ )}\end{array}$ \\
\hline Ashokleyland 63 KVA & 0.00 & 0.00 & 0.00 & -2293 & 0.00 & -2293 \\
\hline Grid & 0.00 & 455601 & 0.00 & 0.00 & 0.00 & 455601 \\
\hline Kirloskar 125KVA & 0.00 & 0.00 & 0.00 & -3153 & 0.00 & -3153 \\
\hline Kirloskar 63KVA & 0.00 & 0.00 & 0.00 & -2580 & 0.00 & -2580 \\
\hline Kirloskar 63KVA Copy & 0.00 & 0.00 & 0.00 & -2580 & 0.00 & -2580 \\
\hline Kirloskar 63KVA (1) & 0.00 & 0.00 & 0.00 & -2580 & 0.00 & -2580 \\
\hline Other & 13846 & 145395 & 0.00 & 0.00 & 0.00 & 159241 \\
\hline
\end{tabular}




\begin{tabular}{|c|c|c|c|c|c|c|}
\hline SolaX X3-hybrid10 & 83100 & 43618 & 43972 & -9977 & 0.00 & 160713 \\
\hline SunPower E20-327 & 307500 & 0.00 & 0.00 & 0.00 & 0.00 & 307500 \\
\hline System & 404446 & 644614 & 43972 & -23164 & 0.00 & 1069868 \\
\hline
\end{tabular}

Table 14. Monthly Grid Energy Exchanges

\begin{tabular}{|c|c|c|c|c|c|}
\hline Month & $\begin{array}{c}\text { Energy } \\
\text { Purchased } \\
\mathbf{( k W h )}\end{array}$ & $\begin{array}{c}\text { Energy } \\
\text { Sold (kWh) }\end{array}$ & $\begin{array}{c}\text { Net Energy } \\
\text { Purchased } \\
\mathbf{( k W h )}\end{array}$ & $\begin{array}{c}\text { Peak } \\
\text { Demand } \\
\mathbf{( k W )}\end{array}$ & $\begin{array}{c}\text { Energy } \\
\text { Charge } \\
\mathbf{( \$ )}\end{array}$ \\
\hline January & 27782 & 44578 & -16795 & 132 & 462.21 \\
\hline February & 27791 & 39254 & -11463 & 150 & 889.40 \\
\hline March & 38055 & 37500 & 555 & 185 & 2518 \\
\hline April & 44207 & 26979 & 17228 & 215 & 4252 \\
\hline May & 14313 & 37332 & -23018 & 65.0 & -911.12 \\
\hline June & 30216 & 15538 & 14678 & 158 & 3138 \\
\hline July & 34913 & 12450 & 22463 & 150 & 4066 \\
\hline August & 40156 & 12684 & 27472 & 188 & 4808 \\
\hline September & 40602 & 18806 & 21796 & 193 & 4383 \\
\hline October & 36386 & 29801 & 6585 & 155 & 2892 \\
\hline November & 30806 & 35841 & -5035 & 135 & 1600 \\
\hline December & 29641 & 43404 & -13763 & 130 & 825.61 \\
\hline Annual & 394868 & 354166 & 40703 & 215 & 28923 \\
\hline
\end{tabular}

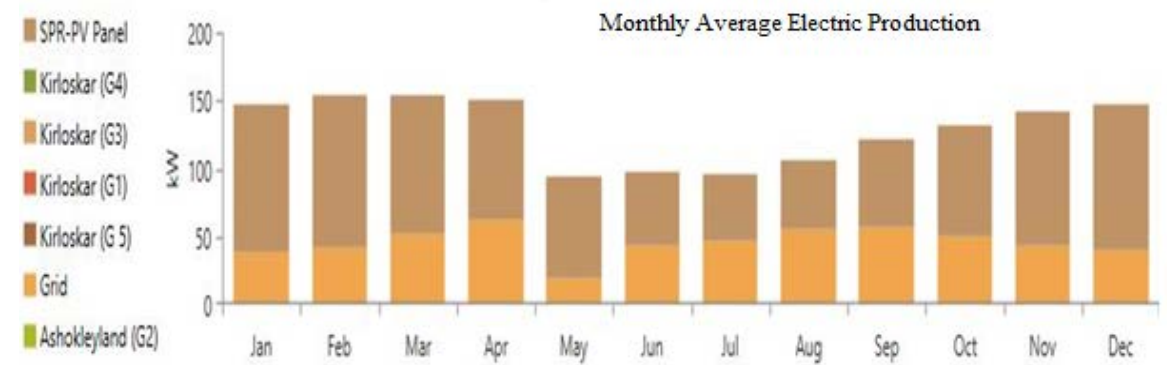

Fig. 13: Monthly average electricity production of optimal hybrid energy system components.

The total net energy procured from the grid is presented in Table 14. It is observed that annually the campus has to pay an amount of $\$ 28923$ to the local utility grid for purchasing electricity. This is due to the fact that the net energy purchase from the grid is increases as compared to the Case 3.

\subsection{Comparison between different integrated energy systems}

A comparative study between four cases of hybrid energy systems are presented in the Table 15 . The results such as initial capital cost, NPC, COE and payback period are compared between four cases. It is seen that the Case 3 has less COE, payback period and NPC as compared to other
Table 15. Comparative study of integrated energy systems

\begin{tabular}{|l|c|c|c|c|}
\hline $\begin{array}{c}\text { Type of } \\
\text { Hybrid } \\
\text { system }\end{array}$ & $\begin{array}{c}\text { Initial } \\
\text { capital } \\
\text { cost(\$) }\end{array}$ & NPC (\$) & $\begin{array}{c}\text { Payback } \\
\text { period } \\
\text { (years) }\end{array}$ & $\begin{array}{c}\text { COE } \\
\text { (\$) }\end{array}$ \\
\hline CASE1 & 589396 & 1752942 & 9 & 0.161 \\
\hline CASE2 & 590546 & 1765177 & 9.8 & 0.162 \\
\hline CASE3 & 409446 & 1056667 & 3.5 & 0.0638 \\
\hline CASE4 & 404446 & 1069868 & 4.4 & 0.0648 \\
\hline
\end{tabular}

cases. However, the initial capital cost of the optimal configuration (Case 3) was slightly more than the Case 4 and less than the Case 1 and Case 2. In the Case 4, the omission of wind turbine leads to the minimizing the overall cost of the Case 4. Further, the overall cost of the Case 1 and Case 2 is more than the Case 3. 


\section{Conclusion}

In this paper, two grid-connected and two stand-alone integrated energy systems are modelled for JNTUKUCEV campus using HOMER Pro. The simulation results show that the On-grid integrated energy systems are more optimal than the stand-alone integrated energy systems. Among the two On-grid hybrid systems the PVWind-Diesel generators- on-grid hybrid system comprising $500 \mathrm{~kW}$ PV panel, five $1 \mathrm{~kW}$ wind turbines, 100 kW Kirloskar generator (G1), 50 kW, Ashokleyland generator (G2), 50 kW Kirloskar generator (G3), 50 kW Kirloskar generator (G4), $50 \mathrm{~kW}$ Kirloskar generator (G5), $300 \mathrm{~kW}$ converter and a grid support of $215 \mathrm{~kW}$ is found to be the best optimal configuration to fulfil the energy needs of the campus. This optimized hybrid energy system produces $1127549 \mathrm{kWh}$ of power to meet the demand. Further, solar panels are contributing its share of $64.5 \%$ of total power generation. $1.07 \%$ of electricity demand is supplied from Whisper wind turbine and $34.4 \%$ electricity demand is supplied from grid. This optimal hybrid energy system releases $\mathrm{CO}_{2}$ of 245423 $\mathrm{kg} / \mathrm{yr}$ and $\mathrm{SO}_{2}$ of $1,064 \mathrm{~kg} / \mathrm{yr}$ in to the atmosphere. The NPC and COE of the optimal hybrid energy system are found to be $\$ 1056668$ and $\$ 0.0638$ respectively. These results could be useful for energy managers and decision makers to select the suitable hybrid energy system for education institutes which are having the similar load profile and geographical conditions to conserve energy and promote green energy utilization.

\begin{tabular}{|c|c|}
\hline $\mathrm{AD}$ & $\begin{array}{l}\text { Nomenclature } \\
\text { Battery's depth of discharge }\end{array}$ \\
\hline $\mathrm{COE}$ & Cost of energy \\
\hline CRF & Capacity recovery factor \\
\hline DOD & Daily autonomy \\
\hline NASA & $\begin{array}{c}\text { National Aeronautics and Space } \\
\text { Administration(-) }\end{array}$ \\
\hline NPC & Net present cost $(\$)$ \\
\hline NREL & National Renewable Energy Laboratory(-) \\
\hline$C_{a n n, t o t}$ & Total annualized cost(\$) \\
\hline$C_{\text {rep }}$ & Replacement cost of the component(\$) \\
\hline$C_{\mathrm{wh}}$ & Storage capacity(kWh) \\
\hline$E_{\text {def }}$ & Total amounts of deferrable load(kWh/year) \\
\hline$E_{\text {grid,sales }}$ & $\begin{array}{c}\text { Amount of energy sold to the grid per } \\
\text { year(kWh/year) }\end{array}$ \\
\hline $\mathrm{E}_{\mathrm{L}}$ & Total energy demand(kWh/year) \\
\hline$E_{\text {prim }}$ & Total amount of primary load(kWh/year) \\
\hline$F$ & Output power of generator(kW) \\
\hline$F_{0}$ & Fuel curve intercept coefficient(L/hr/kW) \\
\hline$F_{1}$ & Fuel curve slope $(\mathrm{L} / \mathrm{h} / \mathrm{kW})$ \\
\hline$G$ & Solar radiation $(\mathrm{W} / \mathrm{m})$ \\
\hline
\end{tabular}

\begin{tabular}{|c|c|}
\hline$G_{\text {ref }}$ & $\begin{array}{l}\text { Solar radiation at reference conditions (Gref } \\
\left.\qquad=1000 \mathrm{~W} \mathrm{~m}^{-1}\right)\end{array}$ \\
\hline$i$ & Annual real interest rate (\%) \\
\hline$K_{\mathrm{T}}$ & $\begin{array}{l}\text { Temperature coefficient of the maximum } \\
\text { power }\left(\% /{ }^{\circ} \mathrm{C}\right)\end{array}$ \\
\hline$N$ & Number of years \\
\hline$P_{g e n}$ & Electrical output of the generator (kW) \\
\hline$P_{\mathrm{NPV}}$ & Rated power at reference conditions (kW) \\
\hline$P_{\text {out }}$ & Output power from the PV cell (kW) \\
\hline$P_{\text {wTG }}$ & Wind turbine power output (kW) \\
\hline$P_{\mathrm{WTG}, \mathrm{STP}}$ & $\begin{array}{l}\text { Wind turbine power output at standard } \\
\text { temperature and pressure }(\mathrm{kW})\end{array}$ \\
\hline$R_{\text {comp }}$ & Lifetime of the component (Years) \\
\hline$R_{\text {proj }}$ & Project lifetime (Years) \\
\hline$R_{\text {rem }}$ & Remaining life of the component (Years) \\
\hline$S$ & Salvage value (\$) \\
\hline$T_{c}$ & Cell temperature $\left({ }^{\circ} \mathrm{C}\right)$ \\
\hline
\end{tabular}

$T$ Temperature at reference conditions (Tref $=$ $25^{\circ} \mathrm{C}$ )

$U_{\text {anem }} \quad$ Wind speed at anemometer height $\left(\mathrm{m} \mathrm{s}^{-1}\right)$

$U_{\text {bub }} \quad$ Wind speed at the hub height of the wind turbine $\left(\mathrm{m} \mathrm{s}^{-1}\right)$

$Y_{\text {gen }} \quad$ Rated capacity of the generator

$Z_{\text {anem }} \quad$ Anemometer height (m)

$Z_{\text {hub }} \quad$ Hub height of the wind turbine (m)

$Z_{\text {o }} \quad$ Surface roughness length (m)

Greek Symbols

$\rho \quad$ Actual air density $\left(\mathrm{kg} \mathrm{m}^{-3}\right)$

$\rho_{0} \quad$ Air density at standard temperature and

$\rho_{0} \quad$ pressure $\left(1.225 \mathrm{~kg} \mathrm{~m}^{-3}\right)$

$\eta_{\mathrm{b}} \quad$ Battery efficiency(\%)

$\eta_{\text {inv }} \quad$ Inverter efficiency(\%)

\section{References}

1) T. Fujisaki, "Evaluation of Green Paradox: Case Study of Japan," Evergreen, 5(4) 26-31(2018). doi:10.5109/2174855

2) R. Sharma, S. Goel, "Stand-alone hybrid energy system for sustainable development in rural India," Environ. Dev. Sustain., 18 (6) 1601-1614 (2016).doi: 10.1007/s10668-015-9705-3

3) H. Kim, S. Baek, E. Park and H. J. Chang, “Optimal green energy management in Jeju, South Korea - Ongrid and off-grid electrification,” Renew. Energy, 69 123-133(2014). doi: 10.1016/j.renene.2014.03.004 
4) S. C. Bhattacharyya, "Mini- grid based electrification in Bangladesh: Technical configuration and business analysis," Renew. Energy, 75 745-761(2015). doi:10.1016/j.renene.2014.10.034

5) S. Bhattacharjee and A. Dey, "Techno-economic performance evaluation of grid integrated PVbiomass hybrid power generation for rice mill," Sustainable Energy Technol. Assess., 7 6-16 (2014). doi:10.1016/j.seta.2014.02.005

6) M. Muselli, G. Notton, and A. Louche, "Design of hybrid photovoltaic power generator,with optimization of energy management," Sol. Energy, 65 143-57(1999). doi:10.1016/S0038092X(98)00139-X

7) Bagen and R. Billinton,"Evaluation of different operating strategies in small standalone power systems,” IEEE Trans. Energy Convers., 20(3) 654660 (2005). doi: 10.1109/TEC.2005.847996

8) T. Givler, P. Lilienthal, "Using HOMER software, NREL's micro power optimization model, to explore the role of gen-sets in small solar power systems case study: Sri Lanka,” Technical Report NREL/TP-71036774, 2005. http://www.osti.gov/bridge.

9) S. Rehman, Md. M. Alam, J.P. Meyer, L. M. AlHadhrami, "Feasibility study of a wind-pv-diesel hybrid power system for a village," Renew. Energy, 38 (1) 258-268 (2012). doi: 10.1016/j.renene.2011.06.028

10) R. Sen, and S. C. Bhattacharya, "Off-grid electricity generation with renewable energy technologies in India: An appli- cation of HOMER,” Renew. Energy, 62 388-398

(2014). doi:10.1016/j.renene.2013.07.028

11) D. Chade, T. Miklis, D. Dvorak, "Feasibility study of wind-to-hydrogen system for arctic remote locationsGrimsey island case study,” Renew. Energy, 76 204211 (2015). doi:10.1016/j.renene.2014.11.023

12) W. M. Amutha, and V. Rajini, "Cost benefit and technical analysis of rural electrification alternatives in southern India using HOMER," Renewable Sustainable Energy Rev., 62 236-246 (2016). doi:10.1016/j.rser.2016.04.042

13) F. Baghdadi, K. Mohammedi, S. Diaf, and O. Behar, "Feasibility study and energy conversion analysis of stand-alone hybrid renewable energy system," Energy Convers. Manage., 105 471-479 (2015). doi:10.1016/j.enconman.2015.07.051

14) A. Singh, and P, Baredar, "Techno-economic assessment of a solar PV, fuel cell, and biomass gasifier hybrid energy system,” Energy Rep., 2 254260 (2016). doi:10.1016/j.egyr.2016.10.001

15) V. Tomar, and G.N. Tiwari, “Techno-economic evaluation of grid connected PV system for households with feed in tariff and time of day tariff regulation in New Delhi - A sustainable approach,”
Renewable Sustainable Energy Rev.,70(C) 822835(2017). doi:10.1016/j.rser.2016.11.263

16) M. Usman, M. Tauseef Khan, A. S. Rana, and S. Ali, "Techno-economic analysis of hybrid solar-dieselgrid connected power generation system,” J. Electr. Syst. Inf. Technol., 5(3) 653-662 (2018). doi:10.1016/j.jesit.2017.06.002

17) Y. V. Pavan Kumar and R. Bhimasingu, "Renewable energy based microgrid system sizing and energy management for green buildings," J. Mod Power Syst. and Clean Energy, 3 1-13 (2015). doi:10.1007/s40565-015-0101-7

18) "NASA Surface meteorology and solar energy," https://eosweb.larc.nasa.gov/sse/. (viewed November 2017)

19) https://elevationmap.net/village-dwarapudivizianagram

20) S. Salehin, M. Tanvirul Ferdaous, R. M. Chowdhury, S. S. Shithi, M.S.R. Bhuiyan Rofi, and M. A. Mohammed "Assessment of renewable energy systems combining techno-economic optimization with energy scenario analysis,” Energy, 112 729-741 (2016). doi:10.1016/j.energy.2016.06.110

21) "Microgrid power system design using HOMER," http://www.homerenergy.com/microgrid_power_syst em_design_services.html.

22) M. L. Kolhe, K.M. Iromi Udumbara Ranaweera, and A.G.B. Sisara Gunawardana, “Techno-economic sizing of Off-grid hybrid renewable energy system for rural electrification in Srilanka," Sustainable Energy Technol. Assess., 11 53-64 (2015). doi:10.1016/j.seta.2015.03.008

23) A. Singh, P. Baredar, and B. Gupta, "Computational simulation \& optimization of a solar, fuel cell and bio mass Hybrid Energy System Using Homer Pro Software,” Procedia Eng., 127 743-750 (2015). doi:10.1016/j.proeng.2015.11.408

24) C. Li , X. Ge , Y. Zheng , C. Xu , Y. Ren, C. Song, and C. Yang. "Techno-economic feasibility study of autonomous hybrid wind/PV/battery power system for a household in Urumqi, China,” Energy, 55 263272 (2013). doi:10.1016/j.energy.2013.03.084

25) S. P. Makhija, and S.P. Dubey, "Feasibility of PVbiodiesel hybrid energy system for a cement technology institute in India,” Environ. Dev. Sustain., 20 377-387 (2018). doi:10.1007/s10668-016-9886-4

26) C. Dennis Barley, and C. Byron Winn,’Optimal dispatch strategy in remote hybrid power systems," Sol. Energy, 58 (4-6) 165-179 (1996). doi:10.1016/S0038-092X(96)00087-4 